\title{
Putative Histone H2B Type 2-C
}

National Cancer Institute

\section{Source}

National Cancer Institute. Putative Histone H2B Type 2-C. NCI Thesaurus. Code C162791.

Putative histone H2B type 2-C (193 aa, $21 \mathrm{kDa}$ ) is encoded by the human H2BC20P gene. This protein may play a role in nucleosomal structure. 